\title{
A NEW CLASS OF POLYPHASE PSEUDO-RANDOM SEQUENCES WITH A NONLINEAR GENERATION ALGORITHM FOR SECURE RADIO COMMUNICATION LINK BETWEEN UNMANNED VEHICLES AND DISPATCH CENTERS OF THE "SMART CITY"
}

Evgeniy M. Lobov,

Moscow Technical University of Communications and Informatics, Moscow, Russia, lobov@srd.mtuci.ru

Dmitry N. Shubin,

Moscow Technical University of Communications and Informatics, Moscow, Russia

Kandaurov A. Nikolai, Moscow Technical University of Communications and Informatics, Moscow, Russia

\section{Elizaveta O. Lobova,}

Moscow Technical University of Communications and Informatics, Moscow, Russia, lizabeth2@mail.ru
DOI: $10.36724 / 2072-8735-2020-\mid 4-8-42-46$

The reported study was funded by $R F B R$, project number 19-29-06055

Manuscript received 02 June 2020; Accepted 10 August 2020

Keywords: pseudorandom sequence, nonlinear sequences, de Bruijn, polyphase sequences, Frank, Chu, Milewski, crypto protection, secure communication systems

\begin{abstract}
The article discusses an algorithm for generating a new class of polyphase pseudo-random sequences with a nonlinear generation algorithm for use in secure communication systems with spread spectrum technology. In particular, the proposed sequences are relevant to use for generating signals in a secure command radio link between unmanned vehicles located in different environments, and dispatch centers of the "smart city". An analysis of the existing ensembles and an assessment of their main characteristics are carried out. Namely, the size of the ensemble, which affects the security of the communication system, and the level of maximum emissions of the cross-correlation function. The existing ensembles of polyphase pseudo-random sequences do not simultaneously have satisfactory values of the considered indicators. Therefore, an urgent task is to develop an ensemble that finds a compromise between these two characteristics and has a nonlinear generation algorithm. The essence of the algorithm for the formation of the proposed new class of polyphase pseudo-random sequences is to expand the classical polyphase sequences, for example, Frank, Chu, or Milewski, which have good correlation properties, de Bruijn sequences with a large ensemble and a nonlinear formation algorithm. Comparative analysis of the proposed method for forming a class of polyphase sequences shows the advantage of its use. In particular, an improvement in cross-correlation characteristics and a significant increase in the size of the ensemble of new sequences compared to the original sequences are shown. These properties can be used to increase the structural secrecy of command radio links.
\end{abstract}

Information about authors:

Evgeniy M. Lobov, Head of a Laboratory, Candidate of Technical Sciences, Docent, Moscow Technical University of Communications and Informatics, Moscow, Russia

Dmitry N. Shubin, Engineer, Moscow Technical University of Communications and Informatics, Moscow, Russia

Kandaurov A. Nikolai, Head of a Laboratory, Candidate of Technical Sciences, Moscow Technical University of Communications and Informatics,

Moscow, Russia

Elizaveta O. Lobova, Post-graduate student, minor researcher, Moscow Technical University of Communications and Informatics, Moscow, Russia

Для цитирования:

Лобов Е.М., Шубин Д.Н., Кандауров Н.А., Лобова Е.О. Новый класс многофазных псевдослучайных последовательностей с нелинейным алгоритмом формирования для защищенных радиолиний связи между беспилотными транспортными средствами и диспетчерскими иентрами "умного города" // Т-Сomm: Телекоммуникации и транспорт. 2020. Том 14. №8. С. $42-46$.

For citation:

Lobov E.M., Shubin D.N., Kandaurov N.A., Lobova E.O. (2020) A new class of polyphase pseudo-random sequences with a nonlinear generation algorithm for secure radio communication link between unmanned vehicles and dispatch centers of the "smart city". T-Comm, vol. 14, no.8, pp. 42-46. (in Russian) 


\section{Introduction}

For modern secure communication systems, an urgent need is to increase transmission secrecy. Spread-spectrum radio technologies are used for this purpose. These technologies require pseudo-random sequences for their work, the characteristics of which directly affect the secrecy of the communication system. In modern communication systems, polyphase pseudo-random sequences with ideal auto-correlation function and small maximum emissions of the cross-correlation function have become widespread. Their main disadvantage is the limited size of the ensemble. Taking into account modern solutions for increasing the secrecy of radio communications, the requirements for the size of the PRS ensemble are increasing. A review of some binary pseudorandom sequences for secure radio communication systems was considered in [1]. This article presents a method for expanding an ensemble of polyphase sequences with de Bruijn binary sequences with a nonlinear formation algorithm, which has a positive effect on the resulting secrecy of the communication system. Also, studies of the cross-correlation function of the resulting polyphase sequences are being carried out.

From all the variety of polyphase PRSs used for spectrum spreading, the polyphase sequences of Frank, Chu, Milewski were chosen as the most frequently used ones.

The proposed new sequences can be used to generate signals for a secure command radio link between unmanned vehicles and dispatch centers of the "smart city".

\section{Analysis of existing ensembles of polyphase sequences}

Frank's polyphase sequences are characterized by an average ensemble size, ideal auto-correlation function, and small maximum emissions of the cross-correlation function. Any Frank sequence is formed according to the following algorithm [2]:

$$
y_{n}^{(r)}=y_{j Q+k}^{(r)}=\alpha^{k j}
$$

where $n$ - number of the element of the PRS. $0 \leq n \leq Q^{2}-1$; $r$ - index of the PRS in ensemble. (r, Q) $=1$ (r coprime with $\mathrm{Q})$; $y$ - PRS element; $Q$ - positive integer; $j, k$ - integers such that $0 \leq j, k<Q$

$$
\alpha=e^{\frac{2 \pi r i}{Q}}
$$

In the Frank set, there are only $\varphi(Q)(\varphi()$-is the Euler function) sequences. The length of the Frank polyphase sequence is $\mathrm{Q}^{2}$. The alphabet is Q-phase.

The set of Chu polyphase sequences [3] consists of $\varphi(Q)$ $(\varphi(Q)$ is the Euler function) sequences, where $\mathrm{Q}$ is a positive integer. The length of the sequence is $\mathrm{Q}$. The alphabet is Qphase, if Q is odd, otherwise the alphabet is 2Q-phase. The formation algorithm is described below:

$$
y_{n}^{(r)}=\left\{\begin{array}{c}
e^{\frac{r n^{2} \pi i}{Q}}, \text { if } Q \equiv 0(\bmod 2) \\
e^{\frac{r n(n+1) \pi i}{Q}}, \text { otherwise }
\end{array},\right.
$$

where $n$ - number of the element of the PRS. $0 \leq n<Q$; $r$ - index of the PRS in ensemble. $(r, Q)=1$ (r coprime with $Q$ ); $y$ - PRS element; $Q$ - positive integer.

The Chu sequences, as well as the Frank, have an ideal autocorrelation function and small maximum emissions of the crosscorrelation function.

In work [4], based on Chu sequences, another family of polyphase sequences was synthesized. These sequences were named after their creator by the Milewski sequences. The formation of these sequences is carried out using the following algorithm:

$$
y_{n}^{(r)}=y_{j Q^{v}+k}^{(r)}=b_{\langle j\rangle_{Q}}^{(r)} \alpha^{r k j},
$$

where

$$
\begin{aligned}
& 0 \leq j<Q^{m+1} \\
& 0 \leq k<Q^{m} \\
& \alpha=\exp \left(2 \pi i / Q^{m+1}\right) \\
& (r, Q)=1 \\
& 0 \leq n \leq Q^{2 m+1}-1 ; \\
& \left\{b_{n}^{(r)}\right\}-\text { Chu sequence of period } \mathrm{Q} . \\
& Q>1, m \text { - positive integer. }
\end{aligned}
$$

Each of the Milewski polyphase sequences has an ideal PAKF. The Milewski sequence alphabet is $\mathrm{Q}^{\mathrm{m}+1}$-phase. The period of the sequences is $\mathrm{Q}^{2 \mathrm{~m}+1}$. The number of polyphase sequences in the Milewski ensemble is equal to $\varphi(Q)(\varphi(Q)$ is the Euler function).

Binary pseudo-random de Bruijn sequences are sequences of maximum length with a nonlinear shaping algorithm [5]. The length of the de Bruijn sequence is $2^{n}$, where $n$ is an integer. A distinctive feature of de Bruijn sequences is the large size of the ensemble. De Bruijn sequences are also known as de Bruijn cycles. One of the ways to form de Bruijn cycles is to use the de Bruijn graph.

Number of de Bruijn sequences of a given length

$$
Q=\frac{(k !)^{k^{n-1}}}{k^{n}},
$$

where $k$-radix; $n=\log _{k}(N), N$ - length of the sequence.

For binary de Bruijn sequences $k=2$ obtain $Q=2^{2^{n-1}-n}$.

Table 1 shows the size of the ensemble depending on the sequence period for the considered types of sequences.

As can be seen from the table Table 1, the ensembles of de Bruijn sequences significantly exceed the volume of ensembles of the considered polyphase PRSs.

The values of the maximum emissions of the crosscorrelation function of the Frank, Chu, Milewski polyphase PRSs of length 64 are shown in Table Table 2.

When studying the cross-correlation properties of de Bruijn sequences, pairs of sequences within an ensemble of sequences of the same length were considered, while the first PRS in a pair was always with index 0 [6].

The values of the maximum emission of cross-correlation function of pairs of sequences are given in Table 3. 
Table 1 The maximum emissions of the cross-correlation function of

The size of the ensembles of the considered PRSs at different PRS length

\begin{tabular}{|c|c|c|c|c|}
\hline $\begin{array}{c}\text { PRS } \\
\text { length }\end{array}$ & $\begin{array}{c}\text { Frank } \\
\text { PPRS }\end{array}$ & $\begin{array}{c}\text { Chu } \\
\text { PPRS }\end{array}$ & $\begin{array}{c}\text { Milewski } \\
\text { PPRS }\end{array}$ & $\begin{array}{c}\text { de Bruijn } \\
\text { BPRS }\end{array}$ \\
\hline 8 & & 4 & 1 & 2 \\
\hline 16 & & 8 & - & 16 \\
\hline 64 & & 32 & 2 & 67108864 \\
\hline 512 & & 256 & 4 & $2^{247}$ \\
\hline 4096 & & 2048 & 8 & $2^{2036}$ \\
\hline 32768 & & 16384 & 16 & $2^{32752}$ \\
\hline
\end{tabular}

Table 2

Maximum emissions of the cross-correlation function of the Frank, Chu, Milewski polyphase PRSs (length 64)

\begin{tabular}{|c|c|c|c|}
\hline PPRS length & Frank PPRS & Chu PPRS & Milewski PPRS \\
\hline 64 & 0,25 & 0,3563 & 0,0988 \\
\hline 512 & & 0,3539 & 0,04789 \\
\hline 4096 & 0, & 0,3536 & 0,02328 \\
\hline
\end{tabular}

Table 3

Maximum emissions of the cross-correlation function of the de Bruijn sequence of length 64 at index 0 with sequences of considered indices

\begin{tabular}{|c|c|c|c|c|c|c|}
\hline Index & & $N_{\max } / 4$ & $N_{\max } / 2$ & $3 N_{\max } / 4$ & $N_{\max }-1$ & $N_{\max }$ \\
\hline $\begin{array}{c}\text { Max } \\
\text { emission }\end{array}$ & 0,8125 & 0,2344 & 0,2500 & 0,2188 & 0,1563 & 0,1563 \\
\hline
\end{tabular}

Thus, we can conclude that de Bruijn sequences with adjacent indices have a high level of cross-correlation. For practical use, de Bruijn sequences with indices located far from each other are suitable as spreading sequences.

\section{A new class of polyphase nonlinear sequences}

To improve the cross-correlation properties of the PRS and increase the ensemble volume, a new class is proposed, formed according to the following algorithm. It is proposed to expand the ensemble of polyphase sequences using de Bruijn sequences with a nonlinear formation algorithm. Namely, depending on the value of the de Bruijn binary sequence symbol, complex conjugation of the polyphase sequence symbol is performed. In this case, each sequence from the Frank (Chu, Milewski) PPRS ensemble is proposed to be extended using the complex conjugation function with the entire ensemble of de Bruijn sequences of a certain length. Because the length of the PPRS of the types under consideration and the de Bruijn NPSP have the same possible values, the question of matching the length of the sequences does not arise.

For a new class of sequences, a study of the correlation properties was carried out, the result is shown in Table 4. the ensemble of sequences are estimated. Used Frank, Chu, Milewski sequences. Expansion using the complex conjugation function of each PPRS of the Frank (Chu, Milewski) ensemble by the de Bruijn sequence with index 0 .

Table 4

Maximum emissions of cross-correlation function of PPRS of a new class inside the ensemble

\begin{tabular}{|c|c|c|c|}
\hline $\begin{array}{c}\text { PPRS } \\
\text { length }\end{array}$ & $\begin{array}{c}\text { Frank PPRS - } \\
\text { de Bruijn } \\
\text { NLPRS (0) }\end{array}$ & $\begin{array}{c}\text { Chu PPRS - de } \\
\text { Bruijn NLPRS } \\
(0)\end{array}$ & $\begin{array}{c}\text { Milewski PPRS - } \\
\text { de Bruijn NLPRS } \\
(0)\end{array}$ \\
\hline 64 & 0,2 & 0,252 & 0,0979 \\
\hline 512 & & 0,2505 & 0,0537 \\
\hline 4096 & & 0,2508 & 0,0257 \\
\hline
\end{tabular}

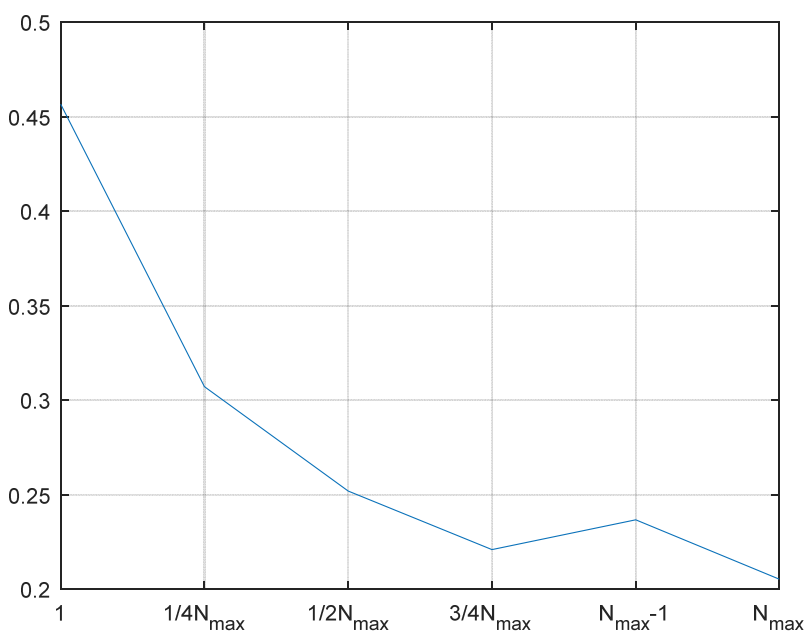

Figure 1. The graph of the maximum emissions of the cross-correlation function of the PRS formed by the Frank PPRS \#0 and the de Bruijn

NLPRS \#0 with the PRS formed by the Frank PPRS \#0 and the de Bruijn NLPRS with different indices

Based on the analysis of Table 4 and comparing the results with Table 2, we can conclude that the maximum emissions of the cross-correlation function for the proposed ensemble are lower than the emissions of the cross-correlation function of the original Frank, Chu PPRS. For the Milewski PPRS, the new class of sequences has the maximum emissions $12 \%$ more in the worst case (for length 512).

It was shown in [6] that the closer the indices of de Bruijn sequences when forming them using a graph, the more they correlate with each other. It was also concluded that it is necessary to choose the indices of de Bruijn sequences to ensure an acceptable level of correlation with the condition of the greatest distance between them, which is confirmed in the previous paragraph by Table 3 .

Figure 1 shows the graphs of the maximum emissions of the cross-correlation function of a new class of sequences formed by the Frank PPRS with index 0 and the de Bruijn NLPRS with 
index 0 when they are cross-correlated with the sequences formed by the Frank PPRS with index 0 and the de Bruijn NLPRS with indices taken at some distance from each other. Table 5 shows the numerical values of the maximum emissions of the cross-correlation function for the sequences involved in plotting the graph in Figure 1. It is clearly seen that the level of correlation drops significantly when using the far-distant de Bruijn NLPRS indices.

Table 5

Maximum emissions of the cross-correlation function

of the sequences of a new class when using Frank PPRS and de Bruijn NLPRS of length 64 with the indicated indices

\begin{tabular}{|c|c|c|c|c|c|c|}
\hline $\begin{array}{c}\text { De Bruijn } \\
\text { NLPRS index }\end{array}$ & 1 & $N_{\max } / 4$ & $N_{\max } / 2$ & $3 N_{\max } / 4$ & $N_{\max }-1$ & $N_{\max }$ \\
\hline Max emission & 0,4567 & 0,3072 & 0,2520 & 0,2210 & 0,2367 & 0,2053 \\
\hline
\end{tabular}

Table 6

Maximum emissions of the cross-correlation function of the sequences of a new class using the Chu and Milevsky PPRS and the de Bruijn NLPRS of length 64 with the indicated indices

\begin{tabular}{|c|c|c|c|c|c|c|}
\hline $\begin{array}{c}\text { De Bruijn } \\
\text { NLPRS indices }\end{array}$ & 1 & $N_{\max } / 4$ & $N_{\max } / 2$ & $3 N_{\max } / 4$ & $N_{\max }-1$ & $N_{\max }$ \\
\hline $\begin{array}{c}\text { Max Emission } \\
\text { (Chu) }\end{array}$ & 0,4621 & 0,2850 & 0,2124 & 0,2290 & 0,2634 & 0,2307 \\
\hline $\begin{array}{c}\text { Max Emission } \\
\text { (Milewski) }\end{array}$ & 0,4678 & 0,2894 & 0,2206 & 0,2258 & 0,2408 & 0,2208 \\
\hline
\end{tabular}

From the results of the study of the cross-correlation function presented in the tables above, it can be concluded that all available de Bruijn NLPRS can be used to expand a single ensemble of polyphase PRSs. But in order to ensure satisfactory crosscorrelation properties resulting from expansion using the complex conjugation function of polyphase PRS and de Bruijn NLPRS, it is necessary to choose de Bruijn NLPRS with satisfactory cross-correlation properties.

Also, a study was carried out of the ensembles of the NLPRS obtained by combining the ensembles of the Chu and Milevsky PPRS and de Bruijn in the same way as above. The results are shown in Table Table 6.

As can be seen from TablesTable 5 andTable 6, the ensemble based on the Frank PPRS has the smallest maximum emissions of the cross-correlation function. This allows us to recommend these polyphase sequence for expansion by de Bruijn sequences.

\section{Conclusion}

A new class of polyphase pseudo-random sequences with a nonlinear generation algorithm is proposed for use in communication systems with increased requirements for secrecy. The increase in the number of PRSs and, accordingly, the size of the ensemble of the signals used, makes it possible to increase the structural secrecy of the command radio link between unmanned vehicles located in different environments and the dispatch centers of the "smart city". At the same time, to improve the correlation properties in comparison with the ensemble of the original multiphase sequences, namely, to reduce emissions of the crosscorrelation function.

The use of the new class of NLPPRS allows increasing the size of the ensemble (for a sequence length of 4096) by $10^{610}$ times compared to the ensemble of the original polyphase sequences, while the level of maximum emissions of the crosscorrelation function of the new sequences is less than the level of the cross-correlation function of the original sequences for the Frank PPRS. To reduce cross-correlations, it is necessary to take de Bruijn sequences with indices located far from each other, i.e. with minimal intersections of the forming graphs.

\section{References}

1. Shubin D.N. (2015). Analiticheskiy obzor ansambley dvoichnyh psevdosluchainyh posledovatelnostey dlia system radiosviazi specialnogo naznacheniya. Trudy NCB MTUCI-2015. ISSN 2221-7975.

2. Frank. (1963). Mnogofaznye cody s horoshimi pereriodicheskimi korreliacionnymi svoistvami. Zarubezhnaia radioelectronika. No. 12, pp. 39-44.

3. Chu D.C. (1972). Polyphase codes with good periodic correlation properties. IEEE Trans. Inf. Theory. Vol. 18, pp. 531-533.

4. Milewski A. (1983). Periodic sequences with optimal properties for channel estimation and fast start-up equalization. IBM J. Res. Dev. Vol. 27. No. 5, pp. 425-431.

5. Meltem Sönmez Turan. (2012). On the Nonlinearity of Maximum-length NFSR Feedbacks. National Institute of Standards and Technology. Cryptography and Communications. December 2012. Vol. 4. Issue 3-4, pp. 233-243.

6. Golubev E.A., Lobov E.M., Kandaurov N.A., Shubin D.N. (2018). Novyi klass dvoichnyh psevdosluchainyh posledovatelnostey s nelineinym algoritmom formirovania dlia system sviazi s kodovym razdeleniem abonentov. T-Comm. Vol 12. No.2, pp. 76-80. 
НОВЫЙ КЛАСС МНОГОФАЗНЫХ ПСЕВДОСЛУЧАЙНЫХ ПОСЛЕДОВАТЕЛЬНОСТЕЙ С НЕЛИНЕЙНЫМ АЛГОРИТМОМ ФОРМИРОВАНИЯ ДЛЯ ЗАЩИЩЕННЫХ РАДИОЛИНИЙ СВЯЗИ МЕЖДУ БЕСПИЛОТНЫМИ ТРАНСПОРТНЫМИ СРЕДСТВАМИ И ДИСПЕТЧЕРСКИМИ ЦЕНТРАМИ "УМНОГО ГОРОДА"

Лобов Евгений Михайлович, Московский технический университет связи и информатики, Москва, Poccuя, lobov@srd.mtuci.ru Шубин Дмитрий Николаевич, Московский технический университет связи и информатики, Москва, Россия Кандауров Николай Александрович, Московский технический университет связи и информатики, Москва, Россия Лобова Елизавета Олеговна, Московский технический университет связи и информатики, Москва, Poсcия, lizabeth2@mail.ru

Исследование выполнено при финансовой поддержке РФФИ в рамках научного проекта № 19-29-06055

\section{Аннотация}

Рассматривается алгоритм генерирования нового класса многофазных псевдослучайных последовательностей с нелинейным алгоритмом формирования для применения в защищенных системах связи с технологией расширения спектра, В частности, предлагаемые последовательности актуально использовать для формирования сигналов в защищенной командной радиолинии между беспилотными транспортными средствами, находящимися в различных средах, и диспетчерскими центрами "умного города". Проводится анализ существующих ансамблей и оценка их основных характеристик. А именно размера ансамбля, влияющего на защищенность системы связи, и уровня максимальных выбросов взаимокорреляционной функции. Существующие ансамбли многофазных псевдослучайных последовательностей не обладают одновременно удовлетворительными значениями рассматриваемых показателей. Поэтому актуальной задачей является разработка ансамбля, находящего компромисс между двумя этими характеристиками и обладающего при этом нелинейным алгоритмом генерации. Сущность алгоритма формирования предлагаемого нового класса многофазных псевдослучайных последовательностей заключается в расширении классических многофазных последовательностей, например, Франка, Чу или Милевского, обладающих хорошими корреляционными свойствами, последовательностями де Брейна, обладающими большим ансамблем и нелинейным алгоритмом формирования. Сравнительный анализ предлагаемого способа формирования класса многофазных последовательностей показывает преимущество его использования. Показано улучшение взаимокорреляционных характеристик и значительное увеличение размера ансамбля новых последовательностей по сравнению с исходными последовательностями. Указанные свойства могут быть использованы для повышения структурной скрытности командных радиолиний.

Ключевые слова: псевдослучайная последовательность, нелинейные последовательности, де Брейн, многофазные последовательности, Франк, Чу, Милевский, криптозащита, защищенные системы связи.

\section{Литература}

І. Шубин Д.Н. Аналитический обзор ансамблей двоичных псевдослучайных последовательностей для систем радиосвязи специального назначения. Труды СКФ МТУСИ. 2015. ISSN 2221-7975.

2. Фрэнк. Многофазные коды с хорошими непериодическими корреляционными свойствами // Зарубежная радиоэлектроника, 1963 , № 12. C. 39-44.

3. Chu. D.C. Polyphase codes with good periodic correlation properties // IEEE Trans. Inf. Theory, Vol. 18, 1972. P. 53 I-533.

4. Milewski A. Periodic sequences with optimal properties for channel estimation and fast start-up equalization // IBM J. Res. Dev, Vol. 27, No. 5, 1983. P. 425-43I.

5. Meltem Senmez Turan "On The Nonlinearity of Maximum-length NFSR Feedbacks. National Institute of Standards and Technology" // Cryptography and Communications, December 2012, Volume 4, Issue 3-4. P. 233-243.

6. Голубев Е.А., Лобов Е.М., Кандауров Н.А., Шубин Д.Н. Новый класс двоичных псевдослучайных последовательностей с нелинейным алгоритмом формирования для систем связи с кодовым разделением абонентов // Т-Сотm: Телекоммуникации и транспорт. 2018. Том I2. №2. С. 76-80.

Информация об авторах:

Лобов Евгений Михайлович, зав. лаб., к.т.н., доцент, Московский технический университет связи и информатики, Москва, Россия Шубин Дмитрий Николаевич, инженер І-й категории, Московский технический университет связи и информатики, Москва, Россия Кандауров Николай Александрович, зав. лаб., к.т.н., Московский технический университет связи и информатики, Москва, Россия Лобова Елизавета Олеговна, аспирант, м.н.с., Московский технический университет связи и информатики, Москва, Россия 